\title{
Priority directions of the energy sector development in the Republic of Turkey
}

\author{
O. V. Luskatova ${ }^{1, *}, R . A$. Eyvazov $^{2}$, and M. M. Haytanova ${ }^{3}$ \\ ${ }^{1}$ Vladimir Branch of Russian Presidential Academy of National Economy and Public Administration, Vladimir, Russia \\ ${ }^{2}$ Diplomatic Academy of the Ministry of Foreign Affairs of the Russian Federation, Moscow, Russia \\ ${ }^{3}$ Vladimir State University, Vladimir, Russia
}

\begin{abstract}
The impact of renewable energy sources on the national economy of the countries across the world will only increase in the near future. It is linked both with the policy of reducing the dependence on imported sources and the opportunities offered by alternative power. Having great prospects for using renewable energy sources in power generation, Turkey has been implementing coherent policy in this field. The article deals with the energy policy Republic of Turkey, analyzes its legislation, studies the trends in the alternative energy sector development as well as the current situation in the domestic power generation.
\end{abstract}

\section{Introduction}

It is common knowledge that energy sources are vital for the country's business life. One of the indicators of stability and welfare of the national economy is the high rate of per capita electricity production. The energy sector makes one of the constituents of the public economic policy. Hence, the economic policy is a set of ideas aimed at strengthening the economic power of the country, and, as a consequence, improving the people's living standards.

As is known, the rise in the electricity production and consumption is intimately related to the high rates of the country's economic development. Therefore, the issues of energy supply make a burning problem to the governments worldwide. The countries that lack own natural resources to satisfy their domestic energy demand are forced to import them or turn to alternative, so-called renewable energy sources (RES).

The Republic of Turkey, which is not rich in mineral resources, has been showing a dynamic growth rate of the national economy within the past 10 to 15 years. Power generation has gone up significantly as well. It is noteworthy that more than half of the electricity produced is generated from the imported energy sources. The aforementioned statement stimulates the Turkish government to take the necessary steps to increase the share of renewable energy in the country's energy sector.

The issues of the rise in the electricity production from alternative sources make the basis of the country's energy policy. Special conditions are created to encourage the development of renewable energy sources; investments are actively attracted; the authorities facilitate the procedures to connect the businesses to the "green" energy networks.

\section{Adaptation of Turkey's power legislation to the EU requirements}

Since the mid-2000s, the Turkish government has been introducing large-scale energy sector reforms. It adopted the legislation to regulate the power sector relations [1].

- Electricity Market Law No.6446 dated 14/03/2013 which replaced the Electricity Market Law of 2001 and the Amendment (2013) [2].

- Natural Gas Market Law No.4646 dated 18/04/2001

- Petroleum Market Law No.5015 dated 04/12/2003

- LPG Market Law and the Amendment to Electricity Market Law No.5307 dated 02/03/2005 [3]

- Law on Utilization of Renewable Energy Sources No.5346 dated 10/05/2005 [4]

- Energy Efficiency Law No.5627 dated 18/04/2007 [5]

- Law on Geothermal Resources and Mineral Waters No.5686 dated 03/06/2007[6]

- Law on Construction and Operation of Nuclear Power Plants and Energy Sale No.5710 dated $09 / 11 / 2007$

Moreover, strategic action plans were developed; the international law was implemented into the national legislation.

Also, it is worth noting the introduction of the EU law in the national legislative system. The Republic of Turkey is bidding to become the EU member state which requires compliance with the certain conditions, including the compliance with the so-called "Copenhagen Criteria". One of the prerequisites of the criteria is: "...ability to take on the obligations of membership including adherence to the aims of political, economic and monetary union" [7].

\footnotetext{
*Corresponding author: oluskatova@mail.ru
} 
This clause forces the bidding countries to introduce the regulatory legal acts issued by the governing bodies into the national legislation.

The main aim of implementing the EU directives in the energy sector was to reduce the role of the public and increase the importance of the market mechanisms. Hence, the issues below are to be resolved:

- creation of an independent power sector regulator,

- implementation of the privatization programme in the fuel and energy sector,

- elimination of obstacles in exploration and production of energy feedstock,

- implementation of investment programmes aimed at the expansion and modernization of oil refineries,

- construction of modern power plants,

- implementation of projects for the installation of new and expansion of the existing transport systems in Turkey.

One of the most significant steps in the fuel and energy system reform in the Republic of Turkey was the creation of the EMRA regulatory body (Energy Market Regulatory Authority EP (EMRA)) [8]. It is authorized to: setting tariffs, preparing subsidiary regulatory acts, issuing licenses, doing necessary market research, etc.

In accordance with the EU directives, the EMRA is a completely independent body both from public and private authorities. Decisions made by the regulator cannot be cancelled by the government.

As a result of the reforms carried out in the power market of the country, the ground was created for independent participants' competition. Private investors got benefits that contributed to an increase in the share of business representatives in power generation.

\section{$3 \quad$ Power improvements energy security \\ production to ensure}

The increasing share of renewable energy in electricity generation reduces the dependence on imported energy sources. No doubt it has a positive effect on the country's energy security and, in general, has a positive effect on the national economy. The on-going improvement of legislation, flexibility of steps, adaptation to external and internal needs (challenges and threats) of the energy sector should become an integral part of the state policy in provision of economic security to the country.

The Turkish government, led by the representatives of the Justice and Development Party, set up ambitious economic goals reflected in a strategic plan called "Turkey's Strategic Vision 2023" [9]. The document dealt with the aims to be achieved by 2023 owing to the economic development, including the power sector.

In 2023 the country will mark a hundredth anniversary of the founding of the Republic of Turkey, and the country's leadership set up a goal to become one of the leading countries in the world. This aim is to be achieved thanks to the developed economy.

The project "Turkey's Strategic Vision 2023" envisages the reduction of the dependence on the imported energy sources by 2023, while increasing the power production from domestic energy resources. Turkey lacks its own natural resources, so it primarily understands renewable power sources under the "domestic" ones. Thus, according to the plan, the share of renewable energy in total power production should reach $32 \%$ by 2023 .

To achieve the above-mentioned result, the country will increase the number of wind-powered stations with a capacity of $20 \mathrm{GW}$ per year by 2023 . As much as 10 GW per year will be produced by solar-powered stations. Over $1 \mathrm{GW}$ is expected from geothermal sources, biomass and other types of alternative energy sources. Meanwhile, the country actively promotes the development of the "green" energy sector. The regulatory framework has been updated. The country creates affordable conditions for investment attraction. Like the UK, France and the Netherlands, Turkey turned to be one of the countries which put over 1bn US dollars in renewable energy investments.

One of the significant steps in the development of the alternative energy sector was the adoption of Law on Utilization of Renewable Energy Sources in 2005. The law says that the government guarantees electricity purchases on reduced tariffs. It applies to all certified RES power producers that launched their businesses before 31 December 2020.

The benefits envisaged by the renewable energy certificates are valid for 10 years. However, the validity period of each renewable energy certificate is one year, and it is subject to annual reissue. The legislation provides various additional incentives to developers of the renewable energy projects, including, in particular:

- The possibility to use forest fund lands and state lands for the construction of power plants based on renewable energy sources and power transmission and/or distribution lines at a discount of 85 per cent of the land use fee charged within the initial 10 years following the investment and/or operation period provided that such a power plant is launched by late 2015 ,

- Reducing pre-licencing fees and licence application fees by 90 per cent,

- Exemption from the annual payment of licence fee within the first 8 years from the date of the object commissioning,

- Priority is given as regards the connection to a transmission or distribution line [10].

Also, the Law on Utilization of Renewable Energy Sources clearly identifies "renewable sources", namely:

- Wind energy,

- Energy of sun,

- Geothermal sources,

- Biomass,

- Biogas,

- Energy of waves, tides and currents (none in Turkey),

- Hydropower resources of the channel or channel type, or reservoir of at least $15 \mathrm{~m} 2$ [4].

The introduction of the Renewable Energy Resources Zone Areas (YEKA) Programme became one of the important events in the alternative power sector development. The status of the RES Zone has already 
Table 1. Power production index evolution on source type ${ }^{\text {a }}$

\begin{tabular}{|c|c|c|c|c|c|c|}
\hline Year & Total (GWh) & Coal (\%) & $\begin{array}{c}\text { Liquid fuels } \\
(\%)\end{array}$ & $\begin{array}{c}\text { Natural Gas } \\
(\%)\end{array}$ & Hydro (\%) & $\begin{array}{c}\text { Renewable Energy and } \\
\text { wastes (\%) }\end{array}$ \\
\hline 2008 & 198418 & 29.1 & 3.8 & 49.7 & 16.8 & 0.6 \\
\hline 2009 & 194813 & 28.6 & 2.5 & 49.3 & 18.5 & 1.2 \\
\hline 2010 & 211208 & 26.1 & 1 & 46.5 & 24.5 & 1.9 \\
\hline 2011 & 229395 & 28.8 & 0.4 & 45.4 & 22.8 & 2.6 \\
\hline 2012 & 239497 & 28.4 & 0.7 & 43.6 & 24.2 & 3.1 \\
\hline 2013 & 240154 & 26.6 & 0.7 & 43.8 & 24.7 & 4.2 \\
\hline 2014 & 251963 & 30.2 & 0.9 & 47.9 & 16.1 & 6.9 \\
\hline 2015 & 261783 & 29.1 & 0.9 & 37.9 & 25.6 & 8.6 \\
\hline 2016 & 274408 & 33.7 & 0.7 & 32.5 & 24.5 & 10.0 \\
\hline 2017 & 297278 & 32.8 & 0.4 & 37.2 & 19.6 & 12.7 \\
\hline 2018 & 303900 & 37.3 & 0.4 & 29.8 & 19.8 & \\
\hline \multicolumn{7}{|l}{ a Compiled by the authors according to the Ministry of Energy and Natural Resources of Turkey } \\
\hline
\end{tabular}

been granted to the city of Karapınar, Konya Province, which has a great potential for solar energy. In addition, an auction was held in Turkey for the construction of solar-powered stations in March 2017. Another similar tender was staged later in August 2017 for the construction of wind-powered plants with a total capacity of $1 \mathrm{GW}$.

In one of his speeches in 2017, Mr Berat Albayrak, Turkish Minister of Energy and Natural Resources, noted that: "...as much as 64 per cent of power plants commissioned within the first 8 months work on renewable energy sources." [11]. In addition, Minister Albayrak shared a plan which envisages the commissioning of power plants on renewable energy sources with a total installed capacity of $45 \mathrm{GW}$ by late 2019 [12].

As a result, the power production from alternative sources hiked by over 800 per cent in 2008-2018. In 2018 the share of renewable energy in electricity production in Turkey, excluding water power plants, totalled 12 per cent (table 1). Despite the deterioration in the rating of the country's investment attractiveness, the growth is viewed as good. Turkey's falling credit ratings is linked with the domestic political and regional crises as well as vagaries in the relationship with the Western countries.

According to the official website of the Ministry of Energy and Natural Resources of 2018, the production of electricity rose by 2.2 per cent year-on-year reaching 303 $900 \mathrm{GW}$. In the distribution pattern of electricity generation by source type, 37.3 per cent belongs to coal, 29.8 per cent to natural gas, 19.8 per cent to hydropower resources, 6.6 per cent to wind energy, 2.6 per cent to solar energy, 2.5 per cent to geothermal sources, 1.4 per cent to other types of resources [13].

Since 2002, the Turkish economy has been developing at a high rate which resulted in the inflation decrease, a rise in the investment attractiveness. The interaction with foreign partners reached a new level; the country has been increasingly introducing and participating in regional projects. The government set a target to become a high-income country and has been consistently working in this direction. However, the domestic political crisis that began in the second decade of the twentieth century, regional armed conflicts, deterioration in relations with foreign partners, the failed coup and pressure from the Western countries, low attractiveness ratings compiled by international organizations contributed to a slowdown in the economic growth [14]. According to the Turkish Statistical Institute and the Ministry of Energy and Natural Resources, the growth in the consumption of renewable energy sources in power generation remains stable [15]. Turkey brings in more than half of the mineral raw materials used in power production which makes obvious the idea of developing alternative energy sources. The Turkish experience is quite positive and can be successfully applied in developing countries (or in middle-income countries), in countries that lack their own power reserves but have great potential in "green" energy sources.

\section{Conclusions}

Summarizing the above, the current Turkish policy in the development of the renewable energy market can be seen as successful. The number of alternative energy power plants has been on the rise as well as the volume of attracted investments. The level of dependence on imported energy sources gradually decreases. The rates of increase in "green" energy production suggests that the goal set in "Turkey's Strategic Vision 2023" - the share of renewable energy in electricity production reaching $1 / 3$ of total power generation - will be achieved, thereby proving the efficacy of the steps taken by as well as plans developed and implemented the government within the framework of the country's energy policy.

\section{References}

[1] Legislation Information System of the Republic of Turkey Ankara URL: http://www.mevzuat.gov.tr/p_KulliyatFihrist.aspx (2019) 
$\begin{array}{llll}{[2] \quad \text { Electricity }} & \text { Market Law 6446, } & \text { dated } \\ \text { Ankara } & & \text { URL: }\end{array}$

http://www.resmigazete.gov.tr/eskiler/2013/03/2013033

$0 . p d f$

[3] LPG Market Law and the Amendment to Electricity Market Law 5307, dated 02/03/2005 Ankara URL: http://www.lawsturkey.com/law/liquefiedpetroleum-gases-lpg-market-law-and-amending-law-toelectricity-market-law-5307

[4] Law on Utilization of Renewable Energy Sources 5346, dated 10/05/2005 Ankara URL: http://www.lawsturkey.com/law/law-on-utilization-ofrenewable-energy-sources-for-the-purpose-ofgenerating-electrical-energy-5346

[5] Energy Efficiency Law 5627, dated 18/04/2007 Ankara URL: http://www.lawsturkey.com/law/energy-efficiency-law5627

[6] Law on Geothermal Resources and Mineral Waters 5686, dated 03/06/2007 Ankara URL: http://www.lawsturkey.com/law/law-on-geothermalresources-and-mineral-waters-5686

[7] European Neighbourhood Policy And Enlargement Negotiations URL: https://ec.europa.eu/neighbourhoodenlargement/policy/conditions-membership en (2019)

[8] Energy Market Regulatory Authority EP URL: $\quad$ https://www.epdk.org.tr/Detay/Icerik/11051/kurumsaltarihce (2019)

[9] Turkey's Strategic Vision URL: http://www.tsv2023.org/ (2023)

[10] R.A. Eyvazov, Strategic directions of Turkey's energy security policy Bulletin of young scientists international. Diplomatic Academy of the Ministry of Foreign Affairs of the Russian Federation 2(2), 10-8 (2017)

[11] Renewable energy attack URL: http://www.milliyet.com.tr/ekonomi/yenilenebilir-enerjiatagi-2536713 (2019)

[12] Minister Albayrak talked about the works and projects carried out by the Ministry of Energy at the Parliamentary Planning and Budget Commission URL: https://www.enerji.gov.tr/tr-TR/Bakanlik-

Haberleri/Bakan-Albayrak-TBMM-Plan-ve-Butce-

Komisyonunda-Enerji-Bakanliginin-Yuruttugu-

Calismalari-ve-Projeleri-Anlatti (2019)

[13] Electricity generation and shares by energy resources The Turkish Statistical Institute URL: http://www.tuik.gov.tr/PreTablo.do?alt_id=1029 (2019)

[14] N.P. Masumova, Foreign trade of turkey: results of liberalization, modern condition and prospects ETAP: economic theory, analysis, practice 1, 82-90 https://elibrary.ru/item.asp?id=37157044 (2019)

[15] Republic of Turkey Ministry of Energy and Natural Resources URL: https://www.enerji.gov.tr/trTR/Sayfalar/Elektrik (2019) 